\title{
Quinolizidine Alkaloid Profiles of Two Taxa of Teline maderensis
}

\author{
Alice Martins ${ }^{\mathrm{a}}$, Michael Wink ${ }^{\mathrm{b}}$, Andreas Tei ${ }^{\mathrm{b}}$, and Amélia P. Rauter ${ }^{\mathrm{a} *}$ \\ a Departamento de Química e Bioquímica, Faculdade de Ciências da Universidade de \\ Lisboa, Ed. C8, 5, Campo Grande, 1749-016 Lisboa, Portugal. Fax: +351217500088. \\ E-mail: aprauter@fc.ul.pt \\ b Institut für Pharmazie und Molekulare Biotechnologie, Universität Heidelberg, \\ Im Neuenheimer Feld 364, 69120 Heidelberg, Germany \\ * Author for correspondence and reprint requests
}

Z. Naturforsch. 58c, 776-778 (2003); received June 10/July 8, 2003

The alkaloid composition of the aerial parts of two taxa of Teline maderensis was studied by capillary GLC and GLC-MS. N-Methylcytisine was the major alkaloid found in both plants. Contents of cytisine and lupanine were higher in T. maderensis var. paivae while anagyrine content was more pronounced in T. maderensis var. maderensis. The alkaloids dehydrocytisine, $\mathrm{N}$-acetylcytisine and epibaptifoline appeared only in $T$. maderensis var. maderensis and $N$-formylcytisine was identified as a minor constituent in $T$. maderensis var. paivae, and detected only in trace amounts in the other variety of the plant.

Key words: Teline maderensis, Quinolizidine Alkaloids, GLC-MS

\section{Introduction}

Teline maderensis Webb et Berthel var. maderensis [syn: Genista maderensis (Webb et Berthel) Lowe] is a rare endemic shrub growing in Madeira, with an approximate height of $5 \mathrm{~m}$, numerous branches, persistent foliage and yellow flowers. It is mainly found in ravines and other localities of Madeira forests (Vieira, 1992).

Teline maderensis Webb et Berthel var. paivae (Lowe) Arco (syn: Genista paivae Lowe) is an extremely rare shrub endemic to Madeira and Desertas Islands. It can attain a height of up to $1.5 \mathrm{~m}$, with abundance of branches, persistent foliage and also yellow flowers, but with a slight morphological difference of the flowers compared to the previously mentioned variety. It grows on hill-sides near the littoral of Madeira and Desertas (Vieira, 1992).

Both plants belong to the Leguminosae family but sometimes the distinction between the two varieties is quite difficult because they are morphologically too close. The analysis of the alkaloid profiles of these two populations by the sensitive techniques GLC and GLC-MS can offer a chance to separate both plants at an intraspecific level.

\section{Materials and Methods}

Plant material

Both plants were collected at the beginning of the flowering period in Madeira Island in June. Their voucher specimens are deposited in Jardim Botânico da Madeira, Funchal, with registration numbers MADJ 8310 for Teline maderensis var. maderensis, collected in S. Jorge, Ribeiro Bonito, and MADJ 8351 for Teline maderensis var. paivae, collected in Vereda das Queimadas, Caldeirão Verde.

\section{Alkaloid extraction}

Dried and powdered aerial parts of both plants (1047 g, T. maderensis var. maderensis; $130 \mathrm{~g}, T$. maderensis var. paivae) were extracted separately with EtOH in a Soxhlet apparatus. The ethanolic extracts were concentrated to dryness under reduced pressure and then acidified with $1 \mathrm{~N} \mathrm{HCl}$ $(\mathrm{pH} 2)$. After filtration (Whatman $\mathrm{n}^{\mathrm{o}} 4$ ), the acid aqueous solutions were basified with concentrated $\mathrm{NH}_{4} \mathrm{OH}$ and extracted with $\mathrm{CH}_{2} \mathrm{Cl}_{2}$. The organic phases were filtered and dried with anhydrous $\mathrm{Na}_{2} \mathrm{SO}_{4}$, filtered again and concentrated in vacuo. The acid base purification was repeated three times to give two dark brown alkaloid residues 
(1.6 g, $\eta=0.15 \%$, T. maderensis var. maderensis; $0.19 \mathrm{~g}, \eta=0.15 \%$, T. maderensis var. paivae).

\section{Alkaloid analysis}

Capillary GLC was performed on a Varian gas chromatograph 3300, equipped with a FID detector and a Spectra Physics Integrator SP4290. Conditions: OV-1 fused silica capillary column $(15 \mathrm{~m} \times$ $0.25 \mathrm{~mm}$ ); carrier gas $\mathrm{He}$; detection temperature $300{ }^{\circ} \mathrm{C}$; injection temperature $250{ }^{\circ} \mathrm{C}$; split 1:20; oven temperature program: initial temperature $120{ }^{\circ} \mathrm{C}, 2 \mathrm{~min}$ isothermal, increased $10^{\circ} \mathrm{C} \mathrm{min}-1$ to $300{ }^{\circ} \mathrm{C}$.

For GLC-MS an OV-1 fused silica capillary column $(30 \mathrm{~m} \times 0.25 \mathrm{~mm})$ was used coupled to a quadropole Finnigan Mat 4515 mass spectrometer. EI-MS were recorded at $40 \mathrm{eV}$ and evaluated with the INCOS DATA SYSTEM. Conditions for alkaloids of T. maderensis var. maderensis: carrier gas $\mathrm{He}$; splitless; oven temperature program: initial temperature $120^{\circ} \mathrm{C}, 2 \mathrm{~min}$ isothermal, $120^{\circ} \mathrm{C}-$ $126^{\circ} \mathrm{C}, 6{ }^{\circ} \mathrm{C} \min ^{-1}, 126{ }^{\circ} \mathrm{C}-300{ }^{\circ} \mathrm{C}, 6{ }^{\circ} \mathrm{C} \min ^{-1}$. Conditions for alkaloids of T. maderensis var. paivae: carrier gas He; split 1:20; oven temperature program: initial temperature $120^{\circ} \mathrm{C}, 3 \mathrm{~min}$ isothermal, $120^{\circ} \mathrm{C}-138^{\circ} \mathrm{C}, 6^{\circ} \mathrm{C} \min ^{-1}, 138^{\circ} \mathrm{C}-300^{\circ} \mathrm{C}$, $6{ }^{\circ} \mathrm{C} \min ^{-1}, 300{ }^{\circ} \mathrm{C}-312{ }^{\circ} \mathrm{C}, 12{ }^{\circ} \mathrm{C} \min ^{-1}$.

Chemical ionization mass spectra (CI-MS) were performed using $\mathrm{NH}_{3}$ as a reactant gas under the same conditions described above.
Kovats retention indices (RI) were calculated by co-injection of standard hydrocarbons.

\section{Results and Discussion}

The identification of the alkaloids was accomplished by comparing their mass spectra and Kovats retention indices (Table I) with those reported in the literature (Wink et al., 1983; Wink, 1993; Wink et al., 1995; El-Shazly et al., 1996; Pistelli et al., 2001; Woldemichael and Wink, 2002).

$\mathrm{N}$-methylcytisine and anagyrine are the major alkaloids found in T. maderensis var. maderensis, while dehydrocytisine, cytisine, rhombifoline, lupanine, $N$-acetylcytisine and epibaptifoline appear in this plant as minor components (Table II). The alkaloids 5,6-dehydrolupanine, aphylline, tinctorine, thermopsine, $\mathrm{N}$-formylcytisine and baptifoline were present only in trace amounts.

In T. maderensis var. paivae we identified $N$ methylcytisine, cytisine and lupanine as major compounds, while $N$-formylcytisine and anagyrine figured as minor constituents (Table II). 5,6-Dehydrolupanine, rhombifoline and tinctorine appeared only in trace amounts.

Quinolizidine alkaloids profiles are of chemotaxonomic value at specific and even subspecific level (Kirch et al., 1995). In this work we reported the alkaloid composition of two populations of $T e$ line maderensis. The chemical data obtained may

Table I. GLC-MS data of quinolizidine alkaloids of Teline maderensis var. maderensis and Teline maderensis var. paivae.

\begin{tabular}{|c|c|c|c|c|}
\hline Alkaloid & RI & $\mathbf{M}^{+}$ & EI-MS & CI-MS \\
\hline$N$-Methylcytisine & 1975 & 204 & 58(100) 117(6) 146(11) 160(9) 204(31) & $205(100)$ \\
\hline Dehydrocytisine & 1985 & 188 & 134(100) 146(61) 148(81) 160(50) 188(98) & n.d. \\
\hline Cytisine & 1995 & 190 & 134(23) 146(100) 147(77) 160(22) 190(63) & $191(100)$ \\
\hline 5,6-Dehydrolupanine & 2148 & 246 & $84(7) 97(38) 98(100) 134(8) 246(17)$ & $247(100)$ \\
\hline Rhombifoline & 2175 & 244 & $58(100) 146(8)$ 160(13) 203(69) 244(2) & $245(100)$ \\
\hline Lupanine & 2182 & 248 & $98(33) 136(100) 149(56) 150(38) 248(39)$ & $249(100)$ \\
\hline Aphylline & 2186 & 248 & $84(34) 96(43) 136(100) 220(36) 248(25)$ & $249(100)$ \\
\hline Tinctorine & 2257 & 244 & $58(31) 146(15) 160(12) 203(100) 244(14)$ & $245(100)$ \\
\hline Thermopsine & 2300 & 244 & $98(100) 136(9) 146(59) 160(13) 244(25)$ & $245(100)$ \\
\hline$N$-Formylcytisine & 2334 & 218 & 134(14) 146(100) 160(17) 190(8) 218(46) & $219(100)$ \\
\hline$N$-Acetylcytisine & 2344 & 232 & $146(100) 147(59) 160(16) 190(8) 232(10)$ & n.d. \\
\hline Anagyrine & 2410 & 244 & $98(100) 136(11)$ 146(14) 160(10) 244(33) & $245(100)$ \\
\hline Baptifoline & 2635 & 260 & $70(36) 96(26) 114(100) 146(20) 260(24)$ & n.d. \\
\hline Epibaptifoline & 2656 & 260 & $70(38) 96(27)$ 114(100) 152(12) 260(36) & n.d. \\
\hline
\end{tabular}

n.d. = not determined. 
Table II. Alkaloid retention times (RT) and contents (total alkaloids $=100 \%$ ) of Teline maderensis var. maderensis and Teline maderensis var. paivae.

\begin{tabular}{ccccc}
\hline \multirow{2}{*}{ Alkaloid } & \multicolumn{2}{c}{ T. maderensis var. maderensis } & \multicolumn{2}{c}{ T. maderensis var. paivae } \\
\cline { 2 - 5 } & RT [min] & Content $(\%)$ & RT [min] & Content $(\%)$ \\
\hline N-Methylcytisine & 9.67 & 57.83 & 9.62 & 38.45 \\
Dehydrocytisine & 9.94 & 0.92 & - & - \\
Cytisine & 10.26 & 4.71 & 10.00 & 30.01 \\
Rhombifoline & 11.56 & 0.42 & tr.d. & 18.17 \\
Lupanine & 11.79 & tr & 13.08 & 1.64 \\
$N$-Formylcytisine & n.d. & 4.70 & - & - \\
$N$-Acetylcytisine & 13.18 & 20.80 & 13.64 & - \\
Anagyrine & 13.71 & 1.75 & - & - \\
Epibaptifoline & 15.93 & & \\
\hline
\end{tabular}

$\operatorname{tr}=$ trace amounts

- $=$ not detected.

n.d. $=$ not determined

be regarded as a complement of other markers such as chromosome numbers and nucleotide sequences of marker genes (Käss and Wink, 1995) for further unambiguous identification of both taxa.

\section{Acknowledgements}

We gratefully acknowledge Susana Fontinha and the staff of the Jardim Botânico da Madeira, Funchal for the collection and identification of plant material. This work was supported by a grant of Fundação para a Ciência e Tecnologia (Portugal), Praxis XXI Program.
Asres K., Tei A., and Wink M. (1997), Quinolizidine alkaloids from the East-African legume Dicraeopetalum stipulare Harms. Biochem. Syst. Ecol. 25, 305-308.

El-Shazly A., Ateya A. M., Witte L., and Wink M. (1996), Quinolizidine alkaloid profiles of Retama raetam, R. sphaerocarpa and $R$. monosperma. Z. Naturforsch. 51c, $301-308$.

Käss E. and Wink M. (1995), Molecular phylogeny of the Papilionoideae (family Leguminosae): RbcL gene sequences versus chemical taxonomy. Bot. Acta 108, $149-162$.

Kirch J., Veit M., Wätzig H., Greinwald R., and Czygan F. C. (1995), Alkaloid variation in Genista lobelii S.I (Fabaceae). Biochem. Syst. Ecol. 23, 635-643.

Mears A. J. and Mabry T. J. (1971), Alkaloids in the Leguminosae. In: Chemotaxonomy of the Leguminosae (Harborne J. B., Boulter D., and Turnner B. L., eds.). Academic Press, London, p. 88

Pistelli L., Bertoli A., Giachi I., Morelli I., Rubiolo P., and Bicchi C. (2001), Quinolizidine alkaloids from Genista ephedroides. Biochem. Syst. Ecol. 29, 137-141.
Vieira R. (1992), Flora da Madeira. O interesse das plantas endémicas macaronésicas (Serviço Nacional de Parques, Reservas e Conservação da Natureza., ed.). Lisboa.

Wink M. (1993). Quinolizidine alkaloids. In: Methods in Plant Biochemistry. Alkaloids and Sulphur Compounds (Waterman P. G., ed.). Academic Press, London, vol. 8, pp. 197-239.

Wink M., Meißner C., and Witte L. (1995), Patterns of quinolizidine alkaloids in 56 species of the genus $\mathrm{Lu}$ pinus. Phytochemistry 38, 139-153.

Wink M., Witte L., Hartmann T., Theuring C., and Volz V. (1983), Accumulation of quinolizidine alkaloids in plants and cell suspension cultures: genera Lupinus, Cytisus, Baptisia, Genista, Laburnum and Sophora. Planta Med. 48, 253-257.

Woldemichael G. M. and Wink M. (2002), Concomitant occurrence of pyrrolizidine and quinolizidine alkaloids in the hemiparasite Osyris alba L. (Santalaceae). Biochem. Syst. Ecol. 30, 139-149. 